\title{
CYP2C8 Inducer
}

National Cancer Institute

\section{Source}

National Cancer Institute. CYP2C8 Inducer. NCI Thesaurus. Code C155921.

Any substance capable of increasing the activity of cytochrome P450 2C8. 